\title{
Sistem Pakar dalam Terapi Penyakit Menggunakan Objek Lidah Manusia dengan Metode Forward Chaining
}

\author{
Yanto Saputra $^{1}$, Jufriadif Na ${ }^{\prime}{ }^{2}{ }^{2}$, Sumijan Sumijan ${ }^{3}$ \\ ${ }^{1,2,3}$ Universitas Putra Indonesia YPTK Padang \\ (Program Studi Teknik Informatika Fakultas Ilmu Komputer Universitas Putra Indonesia \\ YPTK Padang) \\ (Jl. Jl. Raya Lubuk Begalung, Lubuk Begalung Nan XX, Kec. Lubuk Begalung, Kota Padang, \\ Sumatera Barat 25145), (0751) 776666 \\ 1e-mail: yantosaputra1984@gmail.com, ${ }^{2}$ jufriadifnaam@yahoo.com, ${ }^{3}$ soe@upiyptk.org
}

\begin{abstract}
Abstrak
Pemeriksaan lidah merupakan salah satu alat identifikasi yang penting, karena dapat menyajikan tanda-tanda yang jelas terlihat dari kelainan yang dialami penderita. Oleh karena itu, identifikasi penyakit melalui lidah penderita dapat dipertanggungjawabkan kehandalannya. Penelitian ini bertujuan untuk mengidentifikasi syndrome berdasarkan bentuk dan warna lidah serta selaput lidah. Identifikasi ini merupakan informasi awal untuk mendukung keputusan dalam mengambil tindakan terapi. Data yang diolah dalam penelitian ini sebanyak 20 pasien. Data ini bersumber dari Rumah Sehat Daud Pekanbaru yang melakukan konsultasi dan terapi pada pakar pengobatan tradisional Cina Muhammad Dodi, S.E., M.K.M. Metode yang dipakai untuk mengolah data adalah Forward Chaining. Berdasarkan hasil pengolahan yang telah dilakukan untuk menentukan syndrome dan jenis terapi yang diberikan memiliki tingkat akurasi sebesar 100\%. Kemudian adapun hasil dari penelitian ini didapatkan nama syndrome, bentuk dan warna lidah, bentuk dan warna selaput lidah, dan tindakan terapi yang diberikan kepada pasien yang melakukan konsultasi.
\end{abstract}

Kata kunci: lidah, forward chaining, sistem pakar, TCM, terapi

\section{Abstract}

The tongue examination is an important identification tool, because it can present clear signs of the patient's abnormalities. Therefore, the reliability of disease identification through the patient's tongue can be accounted for. This study aims to identify the syndrome based on the shape and color of the tongue and the tongue membrane. This identification is initial information to support decisions in taking therapeutic action. The data processed in this study were 20 patients. This data is sourced from Rumah Sehat Daud Pekanbaru, who conducted consultation and therapy with traditional Chinese medicine expert Muhammad Dodi, S.E., M.K.M. The method used to process data is Forward Chaining. Based on the results of the processing that has been done to determine the syndrome and the type of therapy given has an accuracy rate of $100 \%$. Then as for the results of this study, the name syndrome, the shape and color of the tongue, the shape and color of the tongue membrane, and the therapeutic measures were given to patients who had consultations.

Keywords: tongue, forward chaining, expert system, TCM, therapy 


\section{Pendahuluan}

Inspeksi visual lidah manusia sebagai pendekatan untuk mengidentifikasi kondisi kesehatan manusia dan telah diterapkan dalam berbagai aplikasi medis. Inspeksi visual lidah menawarkan solusi yang sederhana, langsung, murah dan mampu memberikan tanda-tanda penting untuk menggambarkan kondisi kesehatan manusia. Selain itu dalam pengobatan tradisional Cina, lidah sebagai salah satu objek yang paling berharga dan banyak digunakan, lidah telah memainkan peran yang sangat diperlukan selama lebih dari 2000 tahun [1].

Inspeksi visual lidah bertujuan untuk mengetahui daya tahan tubuh pasien, sifat penyakit, lokasi penyakit, dan perkembangan penyakit. Ketika terapis belum bisa memastikan kondisi pasien kekurangan materi ataukah sedang terserang pathogen, maka dapat dilihat dari lidah. Lidah bisa juga dijadikan tolak ukur keberhasilan terapi seseorang pasien [2]. Dari selaput lidah dapat diketahui jenis dan lokasi organ yang bermasalah, karena itu dengan mengamati keadaan lidah dapat diketahui berat-ringannya patogen dan lokasi yang diserang. Misalnya selaput lidah yang tipis umumnya merupakan pertanda penyakit baru timbul, patogen masih dangkal, lokasi penyakit berada pada bagian Piao. Sebaliknya, selaput lidah yang tebal umumnya merupakan pertanda patogen sudah menyerang kedalam, lokasi penyakit sudah berada di dalam. Tubuh lidah berwarna merah tua merupakan pertanda patogen panas sudah menyerang bagian darah dan lokasi penyakit sudah semakin ke dalam, keadaan penyakit sudah gawat. Warna dan sifat selaput lidah selalu berubah mengikuti perkembangan daya tahan tubuh, patogen, dan perkembangan penyakit, hal ini tampak paling nyata dalam serangan patogen panas dari luar. Selain itu, pada penyakit dalam perubahan lidah umumnya selalu mengikuti perkembangan penyakit, misalnya selaput lidah berubah dari warna putih menjadi warna kuning, kemudian menjadi warna abu-abu atau hitam. Gejala itu merupakan ekspresi penyakit berkembang dari bagian Piao ke bagian Li, dari penyakit ringan menjadi penyakit berat dan dari syndrome dingin menjadi syndrome panas. Selaput lidah berubah dari lembab menjadi kering umumnya mencerminkan patogen panas semakin mengganas. Apabila selaput lidah dari tebal berubah menjadi tipis, dari kering berubah menjadi lembab, gejala itu umumnya mencerminkan patogen panas semakin mundur dan Jin Ye sudah pulih kembali. Dalam pengamatan lidah yang perlu diperhatikan, penampilan tubuh lidah dan selaput lidah. Tubuh lidah tersusun dari otot, pembuluh darah, dan jaringan-jaringan yang lain. Sedangkan selaput lidah maksudnya selaput lender yang menutupi permukaan lidah, yang timbul karena adanya Chi dari lambung.

Penampilan lidah yang normal merupakan lidah yang bertubuh lentur, dapat bergerak dengan leluasa, berwarna merah sedang dan cerah, tidak terlalu gemuk atau terlalu kurus, tertutup oleh lapisan selaput lender tipis dengan warna putih, tidak terlalu lembab dan juga tidak terlalu kering. Yang perlu diperhatikan dalam mengamati lidah adalah cahaya, postur menjulurkan lidah dan perubahan selaput lidah karena faktor luar. Pada waktu mengamati lidah, paling baik digunakan cahaya ilmiah yang langsung mengenai lidah. Apabila data yang didapat dari pengamatan malam hari diragukan, maka pengamatan sebaiknya diulang kembali pada siang hari [3].

Namun dalam klinik juga sering dijumpai keadaan yang tidak seperti biasa, misalnya penyakit sudah berat, tetapi keadaan lidah tidak berubah. Sebaliknya, seseorang mempunyai kesehatan baik tetapi mengekspresikan lidah yang abnormal. Karena itu, pengamatan lidah perlu dipadukan dengan data yang di dapat dari pemeriksaan lain, kemudian dianalisis secara menyeluruh sehingga dapat menghasilkan kesimpulan yang tepat. Dalam penelitian ini dilakukan pengujian terhadap 5 data pasien dengan syndrome yang berbeda dan didapat tingkat akurasi sebesar $100 \%$. Seharusnya gangguan penyakit bisa dicegah dan ditangani dengan mudah, apabila tenaga medis atau terapis bisa mengidentifikasi penyakit dengan cepat dan tepat. Sehingga terapi yang diberikan sesuai dengan keluhan pasien. Oleh karena itu, maka dibutuhkan suatu sistem yang memiliki kemampuan untuk dapat mengidentifikasi gejala penyakit melalui objek lidah manusia. Seiring dengan kemajuan teknologi komputer sekarang, teknologi komputer dapat membantu manusia dalam berbagai bidang salah satunya yaitu sistem pakar. Sistem pakar merupakan program komputer yang dirancang untuk memodelkan kemampuan mengatasi masalah seperti seorang pakar [4]. Sistem pakar adalah sistem yang menggunakan 
pengetahuan manusia yang sudah ahli atau pakar dibidang tertentu dan pengetahuan tersebut dimasukkan dan di olah ke sebuah sistem aplikasi yang bisa digunakan untuk menyelesaikan masalah-masalah yang membutuhkan ahli atau pakar [5]. Dengan perkembangan sistem pakar dapat dibuat aplikasi yang dapat mengidentifikasi gejala penyakit dari lidah, dengan berdasarkan warna, lapisan/selapu dan bentuk lidah serta dapat menentukan tindakan terapi yang diberikan. Pada metode penelitian yang sudah diuraikan di atas, maka penulis membuat sebuah Sistem Pakar yang melatar belakangi untuk mengidentifikasi gangguan kesehatan melalui objek lidah manusia dengan metode forward chaining yang nantinya akan membantu terapis untuk menentukan kondisi pasien dan terapi yang diberikan. Keuntungan dengan menggunakan sistem pakar ini adalah proses penentuan identifikasi, analisis dan rekomendasi terapi yang dapat dilakukan dengan mudah [6]. Hal ini sangat membantu masyarakat untuk melakukan identifikasi gejala awal terhadap dirinya sendiri secara konsisten, sehingga dapat mengurangi terjadinya human error dan memberikan penanganan yang baik kepada penderita. Metode forward chaining merupakan salah satu dari metode dalam sistem pakar [7].

Sistem pakar adalah program kecerdasan buatan yang menggabungkan basis pengetahuan (knowledge base) dengan siste inferensi. Inferensi adalah suatu proses untuk memperoleh pengetahuan berdasarkan pengalaman dari pakar. Berdasarkan manfaat dan kemampuan yang diberikan, maka sistem pakar menjadi popular, adapun kelebihan dari sistem pakar di yaitu :

a. Sistem pakar bekerja lebih cepat dari manusia sehingga mampu meningkatkan produktivitas

b. Orang awam mampu bekerja seperti seorang pakar

c. Mampu memberi nasehat yang konsisten layaknya seorang pakar sehingga dapat meningkatkan kualitas layanan.

d. Meningkatkan performa dalam menyelesaikan masalah dikarenakan sumber pengetahuan yang didapatkan dari banyak pakar

e. Untuk seorang pemula yang bekerja dalam sistem pakar, akan terlihat berpengalaman karena adanya fasilitas keterangan yang bisa berfungsi sebagai guru.

Sedangkan untuk kekurangan sistem pakar adalah biaya yang tinggi untuk membuat dan memeliharanya dan sulit untuk dikembangkan. Hal ini disebabkan karena keterbatasan keahlian serta ketersediaan pakar.

\section{Metodologi Penelitian}

Dalam sebuah penelitian, tahapan dalam menyelesaikan suatu masalah sangat perlu agar mencapai hasil yang di inginkan [8]. Data yang diolah dalam penelitian ini adalah bentuk dan warna lidah, keluhan atau gejala pada pasien yang melakukan terapi di Rumah Sehat Daud Pekanbaru. Untuk mengetahui syndrome yang di alami pasien tersebut, dilakukan pengumpulan data dengan studi pustaka dan wawancara.

Kerangka kerja penelitian disusun berdasarkan proses penelitian mulai dari persiapan penelitian, studi literature, observasi di lapangan, pengumpulan data sampai persiapan perancangan sistem pakar [9].

Langkah-langkah dalam penelitian ini disajikan pada Gambar 1 berikut: 


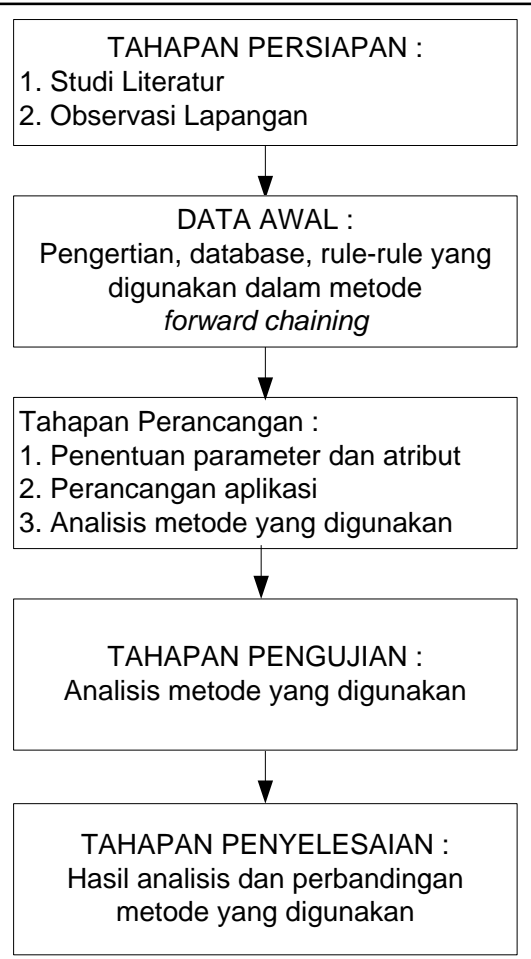

Gambar 1. Kerangka Kerja Penelitian

Berdasarkan kerangka kerja pada Gambar 1, maka disajikan dalam tulisan ini sub proses dari pengolahan data sistem pakar. Sebelum pengolahan data, terlebih dahulu dilakukan tahapan persiapan studi literature dan observasi kelapangan.

Langkah berikutnya yaitu menentukan kriteria keluhan atau gejala yang digunakan dalam melakukan identifikasi syndrome di Rumah Sehat Daud Pekanbaru. Dari data yang diperoleh, maka dilakukan langkah mengidentifikasi lidah pasien dengan melihat bentuk selaput, warna selaput, bentuk badan lidah dan warna badan lidah. Selanjutnya diketahui syndrome yang dialami pasien tersebut dan terapi yang diberikan.

Selanjutnya pengolahan data dengan sistem pakar. Tahapan ini merupakan pengujian aplikasi yang dirancang sebagai implementasi. Implementasi sistem yang dirancang menggunakan metode Forward Chaining [10]. Sistem diuji dengan data kondisi lidah pasien dan gejalanya untuk mengidentifikasi syndrome yang diderita. Tahap-tahapan pengujian adalah sebagai berikut:

a. Sistem pakar berbasis web yang telah dibangun akan mengolah data gejala atau keluhan yang dialami, dan melihat kondisi/bentuk lidah pasien.

b. Hasil pengolahan data pada aplikasi sistem pakar berbasis web akan menghasilkan aturan (rule) dan basis pengetahuan dari seorang pakar.

\section{Hasil dan Pembahasan}

Pada hasil dan pembahasan ini terdapat tahapan analisa dan perancangan sistem. Sistem yang dibangun bertujuan untuk memperoleh hasil pengetahuan serta rule yang berhubungan dengan syndrome.

\section{Analisa dan Perancangan}

Sistem pakar dengan menggunakan metode forward chaining dibutuhkan gejala untuk membuat aturan [11], kemudian aturan yang dihasilkan dapat menentukan jenis terapi yang diberikan kepada pasien berdasarkan bentuk dan warna lidah pasien. Bagan alur analisa perancangan disajikan pada Gambar 2. 


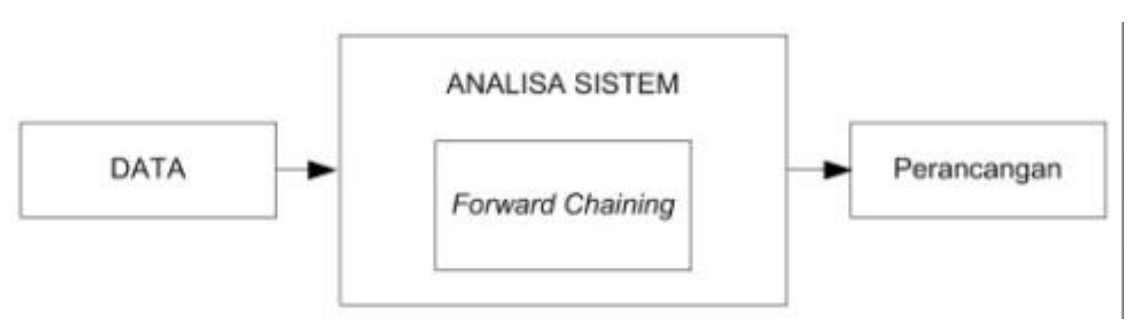

Gambar 2. Tahap Analisa dan Perancangan

\section{Data}

Studi literature dilakukan dengan membaca buku-buku mengenai pengobatan timur dan wawancara dengan pakar pengobatan timur [12]. Data yang diolah bersumber dari Rumah Sehat Daud Pekanbaru. Data digunakan untuk mengidentifikasi syndrome dan menentukan terapi yang diberikan. Data diolah dengan menggunakan metode forward chaining berdasarkan pengetahuan seorang pakar [13]. Dari hasil wawancara beserta penjelasan yang diberikan oleh pakar, terdapat 6 jenis syndrome yang umum yang sering dialami oleh pasien di Rumah Sehat Daud Pekanbaru.

\section{Analisa Sistem}

Dalam tahapan analisa sistem menggunakan metode Forward Chaining. Tahapan prosesnya dimulai dari penelusuran terhadap fakta yang ada [14].

Tahapan prosesnya adalah:

1. Mempersiapkan data input;

2. Menentukan tabel keputusan pakar (ahli);

3. Menentukan rule;

4. Melakukan proses pelacakan;

5. Menentukan pohon keputusan;

6. Hasil pelacakan identifikasi syndrome dan terapi yang diberikan.

\section{Perancangan}

Dari hasil pengisian kuesioner berdasarkan kondisi gejala atau keluhan pasien yang dijawab secara menyeluruh oleh pasien. Dan dilihat kondisi lidah pasien [15]. Sistem dirancang dalam pengolahan data dan prosedur untuk mendukung operasi sistem. Prosedur ini merupakan gambaran perangkat lunak yang dibangun berdasarkan struktur sistem yang telah dibuat. Perancangan antar muka ini meliputi perancangan tabel database, perancangan input dan perancangan output [16].

\section{Arsitektur Sistem}

Arsitektur sistem yang dibangun merupakan implemetasi dari penelititan ini. Bentuk arsitekturnya disajikan pada Gambar 3 berikut: 


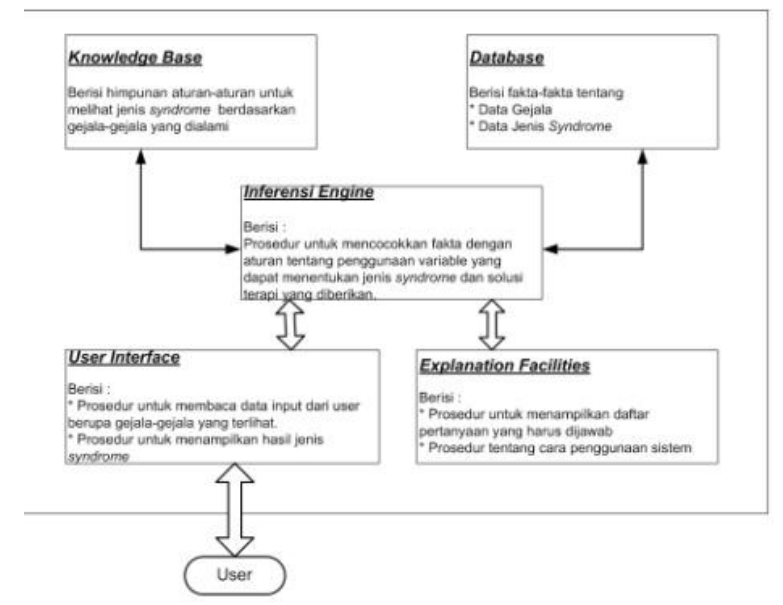

Gambar 3. Arsitektur Sistem Pakar

\section{Knowledge Base}

Pada komponen knowledge base atau basis pengetahuan berisikan pengetahuan yang dibutuhkan [17]. Aturan-aturan yang ditetapkan oleh pakar dalam menentukan terapi. Aturanaturan tersebut adalah jenis syndrome, kondisi lidah dan keterkaitan gejala tersebut dengan jenis syndrome yang berhubungan untuk di lakukan pelacakan pada mesin inferensi.

7. Mempersiapkan Data Input

Dalam observasi lidah yang perlu diperhatikan adalah bentuk badan lidah dan warna badan lidah. Data tersebut didapat di Rumah Sehat Daud Pekanbaru. Berikut rincian data yang dibutuhkan dalam pengolahan data.

Tabel 1. Bentuk Lidah

\begin{tabular}{lc}
\hline Kode & Bentuk Lidah \\
\hline BL01 & Kurus \\
BL02 & Gemuk \\
BL03 & Kaku \\
BL04 & Retak \\
BL05 & Lembek \\
BL06 & Panjang \\
BL07 & Papillae \\
BL08 & Tebal \\
\hline
\end{tabular}

Pada Tabel 1 terdapat keterangan kondisi bentuk lidah manusia yang di beri kode BL dan diikuti nomor urut kodenya.

Tabel 2. Warna Badan Lidah

\begin{tabular}{cc}
\hline Kode & Warna Badan Lidah \\
\hline WL01 & Pucat \\
\hline WL02 & Merah \\
\hline WL03 & Merah Tua \\
\hline WL04 & Abu-abu \\
\hline
\end{tabular}

Pada Tabel 2 terdapat data warna badan lidah yang diberi kode WL dan diikuti nomor urut kodenya. 
Tabel 3. Syndrome

\begin{tabular}{lc}
\hline Kode & Jenis Syndrome \\
\hline SY01 & Panas \\
SY02 & Dingin \\
SY03 & Lembab \\
SY04 & Kering \\
SY05 & Kuat \\
SY06 & Lemah \\
\hline
\end{tabular}
kodenya.

Pada Tabel 3 terdapat data-data syndrome yang diberi kode SY dan diikuti nomor urut

\section{8. $\quad$ Proses Pelacakan dengan Forward Chaining}

Proses pelacakan ini berdasarkan pencocokan pada fakta atau kondisi lidah dengan rules (aturan) yang telah dibuat, beikut ini beberapa contoh hasil proses pelacakan berdasarkan data sampel dari rekap syndrome di Rumah Sehat Daud Pekanbaru, yaitu jenis syndrome dengan masing-masing gejala. Jenis syndrome panas (SY01) dengan kondisi bentuk lidah panjang (BL06), kurus (BL01), kaku (BL03), papillae (BL07), dan warna lidah merah tua (WL03), kemudian syndrome dingin (SY02) dengan kondisi bentuk lidah lembek (BL05), tebal (BL08) dan warna lidah pucat (WL05), kemudian syndrome lembab (SY03) dengan kondisi bentuk lidah gemuk (BL02), dan warna lidah merah (WL02), kemudian syndrome kering (SY04) dengan kondisi bentuk lidah retak (BL04) dan warna lidah merah (WL02), kemudian syndrome kuat (SY05) dengan kondisi bentuk lidah tebal (BL08) dan warna lidah merah (WL02), kemudian syndrome lemah (SY06) dengan kondisi bentuk lidah lembek (BL05) dan warna lidah pucat (WL05).

Berdasarkan data jenis gejala yang diberikan oleh pakar dan dilakukan penyusunan aturan dengan menggunakan metode forward chaining, maka didapat hasil konsultasi dan syndrome yang diderita serta terapi yang diberikan kepada pasien.

Tabel 4. Peta lidah, Syndrome dan Solusi Terapi

\begin{tabular}{cccc}
\hline \multicolumn{2}{c}{ Peta Lidah } & Syndrome & Terapi \\
Bentuk Badan Lidah & Warna Badan Lidah & & Bekam basah \\
\hline $\begin{array}{c}\text { Panjang, kurus, kaku, } \\
\text { Papillae }\end{array}$ & Merah tua & Panas & \\
\hline Lembek, tebal & & & Bekam kering \\
\hline Gemuk & Pucat & Lembab & Bekam kering \\
\hline Retak & Merah & Kering & Bekam basah \\
\hline Tebal & Merah & Kuat & Bekam basah \\
\hline Lembek & Merah & Lemah & Bekam basah \\
\hline
\end{tabular}

Berdasarkan Tabel 4 didapat hasil syndrome dan solusi terapi yang akan diberikan kepada pasien

9. Penyajian Aturan (Rules)

Adapun aturan (rules) untuk melakukan pelacakan dengan metode forward chaining dapat dilihat pada tabel 5 berikut : 
Yanto Saputra, Sistem Pakar dalam Terapi Penyakit Menggunakan Objek Lidah Manusia dengan Metode Forward Chaining

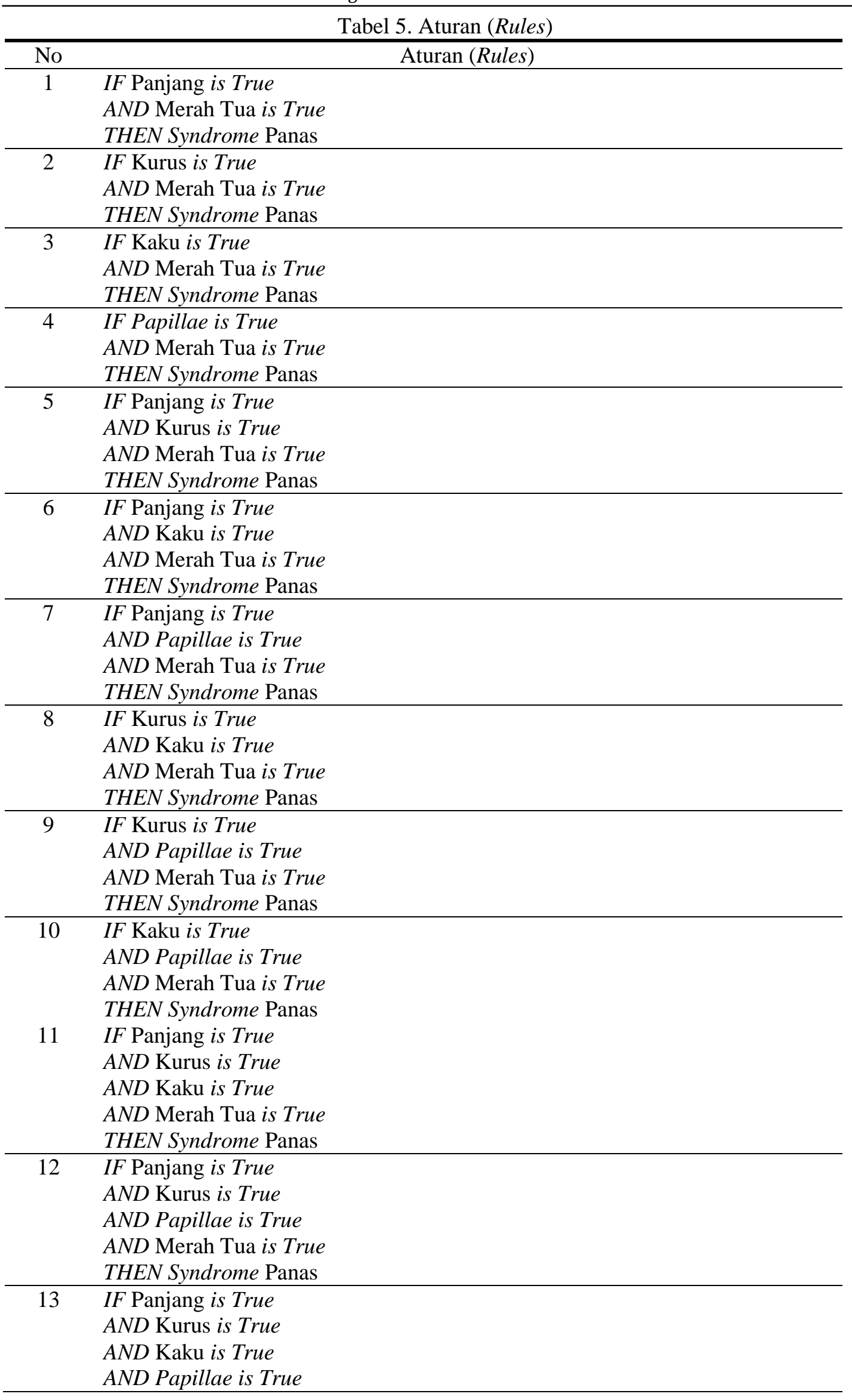




\begin{tabular}{cl}
\hline & AND Merah Tua is True \\
& THEN Syndrome Panas \\
\hline 14 & IF Tebal is True \\
& AND Pucat is True \\
& THEN Syndrome Dingin \\
\hline 15 & IF Gemuk is True \\
& AND Merah is True \\
& THEN Syndrome Lembab \\
\hline 16 & IF Retak is True \\
& AND Merah is True \\
& THEN Syndrome Kuat \\
\hline 17 & IF Lembek is True \\
& AND Pucat is True \\
& THEN Syndrome Lemah
\end{tabular}

Pada Tabel 5 dijelaskan aturan-aturan (rules) yang didapatkan untuk melakukan pelacakan dengan metode forward chaining.

\section{Implementasi Sistem}

Berikut ini pengujian data sampel 5 (lima) orang pasien yang melakukan terapi di Rumah Sehat Daud Pekanbaru seperti pada Tabel 5 berikut.

Tabel 5. Hasil Rule Proses Pelacakan Syndrome

\begin{tabular}{cccc}
\hline No & Pasien & Rule & Jenis Syndrome \\
\hline 1 & Hikmah (01) & IF BL07 AND WL03 THEN SY01 & SY01 \\
\hline 2 & Anton (04) & IF BL08 AND WL01 THEN SY02 & SY02 \\
\hline 3 & Rika (07) & IF BL02 AND BL06 AND WL02 THEN SY03 & SY03 \\
\hline 4 & Anis (18) & IF BL04 AND WL02 THEN SY04 & SY04 \\
\hline 5 & Adri (20) & IF BL02 AND WL02 THEN SY05 & SY05 \\
\hline
\end{tabular}

Pada Tabel 5 dijelaskan sampel kasus diatas yang melalui pelacakan pada tabel, dapat di hasilkan 5 syndrome seperti syndrome panas, syndrome dingin, syndrome lembab, syndrome kering dan syndrome kuat.

Berikut ini adalah tampilan halaman setelah dilakukan pengujian data menggunakan sistem pakar yang sudah dirancang. Hasil konsultasi Nyonya Hikmah dapat dilihat pada Gambar 4.

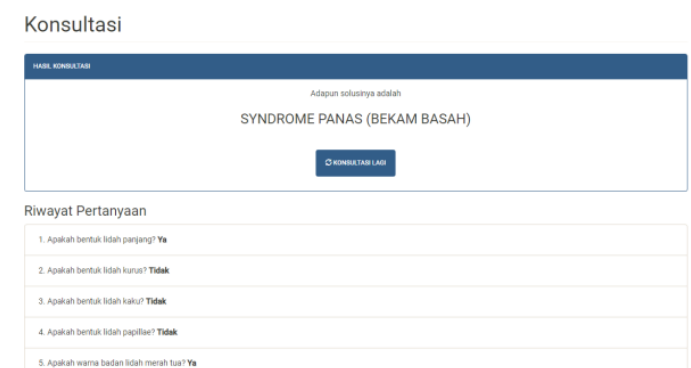

Gambar 4. Hasil Pengujian pada Nyonya Hikmah

Hasil penelusuran sistem berdasarkan kondisi lidah yang di input pada sistem membuktikan bahwa kondisi Nyonya Hikmah mengalami syndrome panas sesuai dengan data uji/sample pertama. Selanjutnya dilakukan pengujian data kedua atas nama Tuan Anton dapat dilihat pada Gambar 5. 


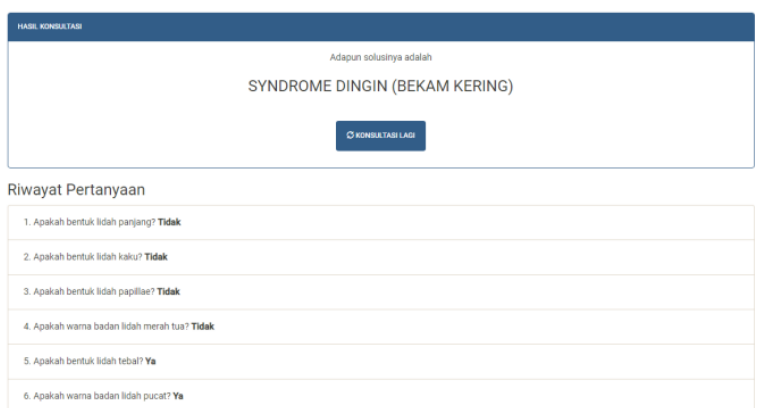

Gambar 5. Hasil Pengujian pada Tuan Anton

Hasil penelusuran sistem berdasarkan kondisi lidah yang di input pada sistem membuktikan bahwa kondisi Tuan Anton mengalami syndrome dingin sesuai dengan data uji/sample kedua. Selanjutnya dilakukan pengujian data ketiga atas nama Nyonya Rika dapat dilihat pada Gambar 6.

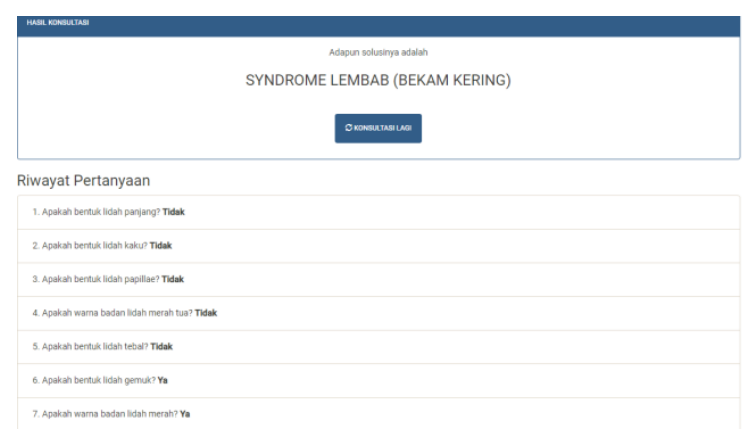

Gambar 6. Hasil Pengujian pada Nyonya Rika

Hasil penelusuran sistem berdasarkan kondisi lidah yang di input pada sistem membuktikan bahwa kondisi Nyonya Rika mengalami syndrome lembab sesuai dengan data uji/sample ketiga. Selanjutnya dilakukan pengujian data keempat atas nama Nyonya Anis dapat dilihat pada Gambar 7.

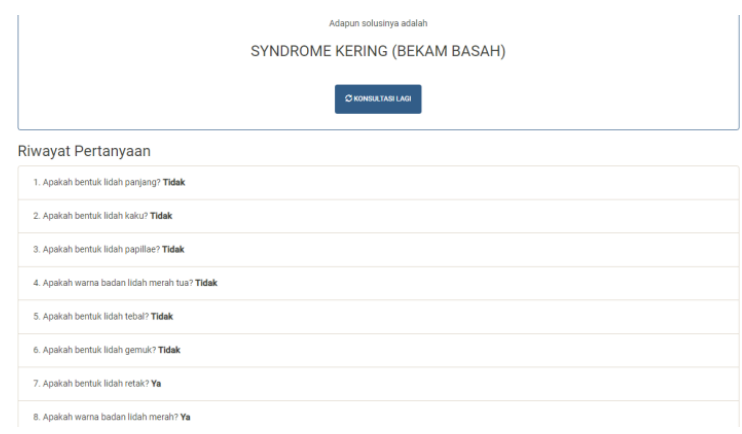

Gambar 7. Hasil Pengujian pada Nyonya Anis

Hasil penelusuran sistem berdasarkan kondisi lidah yang di input pada sistem membuktikan bahwa kondisi Nyonya Anis mengalami syndrome kering sesuai dengan data uji/sample keempat. Selanjutnya dilakukan pengujian data kelima atas nama Tuan Adri dapat dilihat pada Gambar 8 


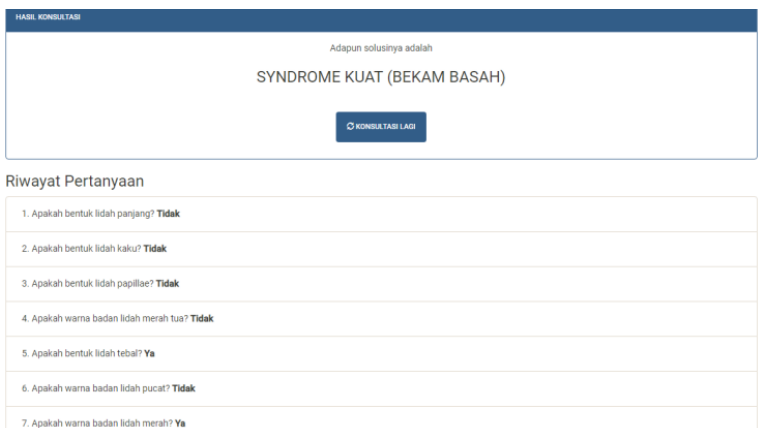

Gambar 8. Hasil Pengujian pada Tuan Adri

Hasil penelusuran sistem berdasarkan kondisi lidah yang di input pada sistem membuktikan bahwa kondisi Tuan Adri mengalami syndrome kuat sesuai dengan data uji/sample kelima.

\section{Kesimpulan}

Berdasarkan uraian yang telah dibahas pada laporan penelitian serta hasil pembahasan. Melalui sistem pakar menggunakan metode forward chaining mampu memberikan dampak yang positif kepada terapis dalam memberikan terapi yang tepat kepada pasien sehingga terhindar dari hal-hal yang tidak di inginkan (malpraktek). Penggunaan sistem pakar metode forward chaining sangat mudah, terapis hanya menjawab pertanyaan-pertanyaan yang muncul di layar sesuai dengan kondisi lidah pasien saat melakukan konsultasi sampai sistem mengeluarkan rekomendasi terapi yang diberikan kepada pasien tersebut. Untuk penelitian selanjutnya diharapkan dapat memperbaharui syndrome dan penyempurnaan idenfikasi penyakit melalui lidah manusia dan titik-titik terapi bekam yang akan dilakukan.

\section{Daftar Pustaka}

[1] Zhang, David., Zhang, Hongzhi., Zhang, Bob. (2017). Tongue Image Analysis. 2017. Singapore : Springer Nature

[2] Ridho, Achmad Ali. (2017). Bekam Sinergi (Rahasia Sinergi Pengobatan Nabi, Medis Modern dan Traditional Chinese Medicine Cetakan ke Tiga. 2017. Solo : PT. Aqwam Media Profetika

[3] Jie, Sim Kie. (1997). Dasar Teori Ilmu Akupunktur Identifikasi dan Klasifikasi Penyakit. 1997. Jakarta : PT. Gramedia Widiasarana Indonesia

[4] Pratiwi, H. I., \& Kamardi, R. (2019). Pengembangan Sistem Web Sebagai Diagnosa Dini Penyakit Alergi Kulit Dermatitis Atopik Dengan Metode Forward Chaining. Widyakala : Journal Of Pembangunan Jaya University, 6(2), 167-174.

DOI : https://doi.org/10.36262/widyakala.v6i2.219

[5] Afdal, M., \& Humani, D. G. (2020). Aplikasi Sistem Pakar Diagnosa Awal Penyakit Menular Pada Balita Berbasis Android. Jurnal Ilmiah Rekayasa dan Manajemen Sistem Informasi, 6(1), 55-63.

DOI : http://dx.doi.org/10.24014/rmsi.v6i1.8979

[6] Herman, A., \& Darmawan, F. (2020). Sistem Pakar Mendiagnosa Penyakit Campak Dan Rubella Dengan Metode Forward Chaining Berbasis Web. ENSAINS JOURNAL, 3(1), 51-59.

DOI : https://doi.org/10.31848/ensains.v3i1.372

[7] Kurniawan, A. (2019). Sistem Pakar Mendiagnosa Penyakit Flu Burung Secara Online Dengan Metode Forward Chaining. JIKA (Jurnal Informatika), 2(1).

DOI : http://dx.doi.org/10.31000/jika.v2i1.1414

[8] Putra, H. W. (2019). Sistem Pakar Diagnosis Penyakit Ginjal Dengan Metoda Forward Chaining. Jurnal Sains dan Informatika: Research of Science and Informatic, 5(1), 7-12. DOI : http://doi.org/10.22216/jsi.v5i1.4081 

Metode Forward Chaining

[9] Rahman, A. F. S. (2019). Sistem Pakar Mendiagnosa Penyakit Kolesterol Berbasis Database Dan Web. Jurnal Teknik Elektro Uniba (JTE Uniba), 4(1), 29-35.

DOI : https://doi.org/10.36277/jteuniba.v4i1.52

[10] Walhidayat, W., \& Nanda, R. (2019). Sistem Pakar Diagnosa Penyakit Gigi Menggunakan Metode Forward Chaining (Studi Kasus: Klinik Gigi drg. Tetra Asmira Teluk Kuantan). JURTEKSI, 5(2), 147-152.

DOI : https://doi.org/10.33330/jurteksi.v5i2.344

[11] Wahyuni, R. (2019). Jurnal Aplikasi Sistem Pakar Untuk Diagnosa Penyakit Campak Dan Pencegahan Dengan Metode Forward Chaining Berbasis Web. Jurnal Ilmu Komputer, 8(2), 53-59.

DOI : https://doi.org/10.33060/JIK/2019/Vol8.Iss2.128

[12] Suharningsih, T. E., Wijaya, I. G. P. S., \& Husodo, A. Y. (2019). Sistem Pakar Penyakit Mata Merah Berbasis Web Menggunakan Metode Decision Tree dengan Forward Chaining. Jurnal Teknologi Informasi, Komputer, dan Aplikasinya (JTIKA), 1(1), 57 64. DOI: https://doi.org/10.29303/jtika.v1i1.2.

[13] Husin, A., Faren, M. P., \& Usman, U. (2019). Sistem Pakar Pendeteksi Penyakit Berdasarkan Keluhan Buang Air Kecil Menggunakan Metode Forward Chaining. Jurnal Ipteks Terapan, 12(4), 277-285.

DOI : http://doi.org/10.22216/jit.2018.v12i4.2490

[14] Hairani, H., Abdillah, M. N., \& Innuddin, M. (2019). Perancangan Sistem Pakar Diagnosis Penyakit Rematik Menggunakan Inferensi Forward Chaining Berbasis Prolog. InfoTekJar: Jurnal Nasional Informatika dan Teknologi Jaringan, 4(1), 8-11. DOI : https://doi.org/10.30743/infotekjar.v4i1.1377

[15] Khawarizmi, I. N., Triayudi, A., \& Sholihati, I. D. (2020). Diagnosa Depresi Pada Mahasiswa Menggunakan Metode Certainty Factor dan Forward Chaining. INTI Nusa Mandiri, 14(2), 139-144.

DOI : https://doi.org/10.33480/inti.v14i2.1173

[16] Gusman, A. P., Maulida, D., \& Rianti, E. (2019). Sistem Pakar Diagnosa Penyakit Kista Ovarium Dengan Metode Forward Chaining. Jurnal KomtekInfo, 6(1), 8-18.

DOI : $\underline{\text { https://doi.org/10.29165/komtekinfo.v6i1.146 }}$ 